\title{
PENGARUH PEMBERIAN ASI DAN STIMULASI PSIKOSOSIAL TERHADAP PERKEMBANGAN SOSIAL-EMOSI ANAK BALITA PADA KELUARGA IBU BEKERJA DAN TIDAK BEKERJA
}

Influence of Breastfeeding and Psychosocial Stimulation to Child's Social-Emotion Development on Family whose Working Mother and Unworking Mother

\author{
EVA LATIFAH ${ }^{1}$, DWI HASTUTI ${ }^{2}$, MELLY LATIFAH ${ }^{2 *}$ \\ ${ }^{1}$ Program Studi Gizi Masyarakat dan Sumberdaya Keluarga, Fakultas Pertanian, Institut \\ Pertanian Bogor, Kampus Dramaga, Bogor 16680 \\ ${ }^{2}$ Staf Pengajar Departemen Ilmu Keluarga dan Konsumen, Fakultas Ekologi Manusia, \\ Institut Pertanian Bogor, Jalan Lingkar Kampus IPB Dramaga, \\ Bogor 16680
}

\begin{abstract}
The aims of this research were to know characteristics of family and child who come from family whose working mother and unworking mother; to analyze the differences of breastfeeding and psychosocial stimulation between two groups; to analyze the correlation between characteristics family and child, with breastfeeding and psychosocial stimulation; and to analyze the impact of breastfeeding and psychosocial stimulation toward child's social-emotion development. A cross sectional design was applied in this research. This research represented the part of Yuliati's (2006) research which entitled "Study of behavior buying and consuming milk for 2-5 years old of child and impact to child's growth and development". Population in this research represented sample from Yuliati's research that were selected by purposive with criteria 3,5-5 years old of children who come from family whose working mother and unworking mother. The result showed that there were not significant differences between characteristics of family and child, duration of breastfeeding and psychosocial stimulation between two groups. Correlation test of Rank Spearman showed that only father's education and family's income that had significantly negative correlation with duration of breastfeeding. Meanwhile, father's education, mother's education, family's income and mother's knowledge about child's growth and development significantly had positive correlation with psychosocial stimulation. Based on gender, girl significantly had higher psychosocial stimulation than buy. Psychosocial stimulation and child's age were dominant factor in influencing child's social-emotion development, while duration of breastfeeding was not influencing.
\end{abstract}

Key words: breastfeeding, development, psychosocial, social-emotion, stimulation

\section{PENDAHULUAN}

Kualitas anak dapat dilihat dari dua dimensi, yaitu pertumbuhan dan perkembangan. Dua faktor utama yang mempengaruhi tumbuh kembang seorang anak, yakni faktor dalam (bawaan) dan faktor luar (lingkungan). Masa lima tahun pertama dikatakan sebagai masa terbentuknya dasar kepribadian manusia. Oleh karena itu faktor luar perlu diperhatikan agar dasar-dasar pembentukan kepribadian anak dapat diletakkan secara kokoh dan mantap. Dalam hal ini, keluarga mempunyai peranan yang sangat penting (Darmadji et al. 1984).

\begin{abstract}
Perubahan zaman ke arah yang lebih modern dapat mempengaruhi institusi keluarga. Jumlah wanita yang bekerja di luar rumah semakin meningkat, baik karena alasan aktualisasi diri maupun alasan kebutuhan ekonomi. Hal ini juga dipicu oleh kebijakan pemerintah yang mendorong para wanita untuk berperan aktif di luar rumah. Bagi perempuan yang mencari aktualisasi diri, biasanya anak setelah dilahirkan usia dua bulan sudah ditinggalkan seharian penuh dan diasuh oleh orang lain atau dimasukkan tempat penitipan anak (Megawangi 2004). Adanya ibu bekerja dengan cuti hamil tiga bulan, akan menjadi
\end{abstract}


suatu alasan bagi ibu bekerja untuk tidak memberikan ASI sesudah masa cuti berakhir (Roesli 2000).

Praktek pengasuhan dalam hal ini pemberian stimulasi psikososial dan ASI dapat mempengaruhi perkembangan anak. Departemen Pendidikan Nasional (2002) menyatakan bahwa stimulasi psikososial merupakan stimulasi pendidikan dalam rangka mengembangkan kemampuan kognitif, motorik, serta sosial-emosi anak. Roesli (2000) menambahkan bahwa interaksi ibu dan bayi melalui pemberian ASI akan memberikan kesempatan pada bayi untuk tumbuh menjadi manusia yang mempunyai emosi yang lebih stabil dan perkembangan sosial yang lebih baik.

Oleh karenanya penelitian ini bertujuan untuk: (1) mengidentifikasi karakteristik keluarga dan anak pada keluarga ibu bekerja dan tidak bekerja; (2) menganalisis perbedaan pemberian ASI dan stimulasi psikososial pada ibu bekerja dan tidak bekerja; (3) menganalisis hubungan karakteristik keluarga dan anak dengan pemberian ASI dan stimulasi psikososial; (4) menganalisis pengaruh pemberian ASI dan stimulasi psikososial terhadap perkembangan sosial-emosi anak balita.

\section{METODE}

\section{Desain, Lokasi, dan Waktu}

Desain penelitian ini adalah crosssectional study. Penelitian ini merupakan bagian dari penelitian payung Yuliati (2006) yang berjudul "Studi Perilaku Pembelian dan Konsumsi Susu untuk Anak Usia 2-5 Tahun dan Dampaknya terhadap Pertumbuhan dan Perkembangan". Penelitian dilakukan di dua kecamatan, yaitu Kecamatan Bogor Timur (Kelurahan Baranangsiang dan Sukasari) dan Kecamatan Tanah Sareal (Kelurahan Tanah Sareal dan Kedung Badak). Pemilihan lokasi dilakukan secara purposive dengan pertimbangan bahwa wilayah tersebut dekat dengan pertokoan, mall, supermarket, atau departemen store sebagai tempat penjualan berbagai merek susu formula. Sementara itu, pemilihan RW dilakukan secara purposive dengan pertimbangan bahwa RW tersebut memiliki jumlah balita cukup tinggi. Waktu penelitian termasuk persiapan, pengumpulan data, pengolahan, dan analisis data serta penulisan laporan adalah sebelas bulan terhitung mulai bulan April 2006 sampai Maret 2007.

\section{Penarikan Contoh}

Populasi penelitian ini adalah anak balita berusia 2-5 tahun yang berada di wilayah terpilih. Teknik penarikan contoh dilakukan secara bertahap, dimana populasi target penelitian ini merupakan contoh dari penelitian Yuliati (2006) yang dipilih secara purposive dengan kriteria anak balita berusia 3,5-5 tahun yang berasal dari keluarga dengan ibu bekerja dan tidak bekerja sehingga diperoleh populasi target sejumlah 182.

Dari populasi target tersebut kemudian dipilih secara acak proporsional sejumlah 100 contoh agar dapat memenuhi jumlah contoh minimal yang diperlukan, dimana 27 contoh berasal dari keluarga ibu bekerja dan 73 contoh berasal dari keluarga ibu tidak bekerja. Adapun formulasi perhitungan jumlah contoh minimal berdasarkan rumus Slovin (1997) diacu dalam Umar (2000) dengan derajat kepercayaan yang diinginkan adalah $90 \%$ dan presisi $10 \%$ adalah sebagai berikut:

$$
\mathrm{n}=\frac{\mathrm{N}}{1+N e^{2}}
$$

$\mathrm{n}$ = jumlah contoh

$\mathrm{N}$ =jumlah populasi

e =persen kelonggaran ketidaktelitian karena kesalahan pengambilan sampel yang masih dapat ditolerir atau diinginkan.

$$
\begin{aligned}
n & =\frac{182}{1+182(0,1)^{2}} \\
& =64,5 \approx 65 \text { orang contoh }
\end{aligned}
$$

\section{Jenis dan Cara Pengumpulan Data}

Data yang dikumpulkan dalam penelitian ini terdiri atas data primer dan data sekunder. Data primer diperoleh dengan pengamatan dan wawancara langsung dengan menggunakan alat bantu kuesioner yang terdiri dari data:

1. Karakteristik keluarga (pendidikan orangtua, pendapatan keluarga, pengetahuan tumbuh kembang, dan status pekerjaan ibu).

2. Karakteristik contoh (umur dan jenis kelamin).

3. Pengetahuan ibu mengenai tumbuh kembang diukur dengan mengajukan sepuluh pertanyaan. 
4. Stimulasi psikososial diukur dengan menggunakan indicator Home Observation for Measurement of the Environment (HOME). Indikator HOME untuk anak usia $>3$ tahun terdiri dari 55 pertanyaan dengan total skor $0-55$ poin, terbagi dalam delapan subskala (stimulasi belajar, stimulasi bahasa, lingkungan fisik, kehangatan, dan kasih sayang, stimulasi akademik, modelling, variasi pengalaman, dan penerimaan).

5. Pemberian ASI terdiri atas data lama pemberian ASI.

6. Perkembangan sosial-emosi anak diukur dengan melakukan wawancara pada ibu serta pengamatan pada contoh dengan menggunakan checklist observasi instrumen penelitian kompetensi (perkembangan) anak usia 3,5-6,4 tahun yang disusun oleh Depdiknas (2004), dengan total skor 024 poin, terbagi dalam dua subskala (respon anak tentang diri sendiri dan keluarga dan respon anak tentang orang lain, peran dan perasaan).

Penelitian ini juga mengumpulkan data sekunder yang meliputi keadaan umum lokasi penelitian dan data jumlah balita yang diperoleh dari kantor kecamatan, kelurahan, dan posyandu.

\section{Pengolahan dan Analisis Data}

Data yang diperoleh diolah melalui proses editing, coding, scoring, entry data ke komputer, cleaning data, dan analisis data dengan bantuan komputer menggunakan program Microsoft Excel dan SPSS for Windows. Analisis data dilakukan secara statistik deskriptif dan inferensia. Analisis awal dilakukan secara statistik deskriptif. Setelah itu, dilakukan analisis secara statistik inferensia untuk melihat adanya perbedaan variabel antara keluarga ibu bekerja dan tidak bekerja dengan menggunakan uji beda Mann-Whitney untuk data berskala minimal nominal dan uji T-test untuk data berskala minimal interval. Analisis korelasi Rank Spearman dilakukan untuk melihat hubungan antar variabel yang diteliti, selanjutnya untuk melihat faktor-faktor dominan yang mempengaruhi perkembangan sosial-emosi anak dilakukan Regresi Linier Berganda.

\section{HASIL DAN PEMBAHASAN}

\section{Karakteristik Keluarga}

Pendidikan orangtua dikelompokkan menjadi lima tingkat, yaitu tidak sekolah, tamat SD, tamat SMP, tamat SMA, dan tamat Perguruan Tinggi. Berdasarkan hasil penelitian dapat diketahui lebih dari separuh ayah contoh, baik pada keluarga ibu bekerja $(51,9 \%)$ maupun pada keluarga ibu tidak bekerja $(52,1 \%)$, memiliki tingkat pendidikan SMA, serta tidak ada satu pun yang tidak pernah sekolah. Sementara itu, persentase ibu dengan tingkat pendidikan SMA lebih besar pada ibu tidak bekerja (25,9\% pada ibu bekerja dan $43,8 \%$ pada ibu tidak bekerja). Namun, persentase ibu dengan tingkat pendidikan Perguruan Tinggi lebih besar daripada ibu bekerja $(11,1 \%$ pada ibu bekerja dan $4,1 \%$ pada ibu tidak bekerja). Rata-rata lama pendidikan ibu contoh, baik pada keluarga ibu bekerja dan keluarga ibu tidak bekerja, relatif sama yakni masingmasing 9,7 tahun dan 9,8 tahun. Hasil uji statistik menyatakan tidak terdapat perbedaan yang signifikan antara lama pendidikan ayah dan ibu contoh pada keluarga tidak bekerja.

Hasil penelitian menunjukkan bahwa persentase terbesar pendapatan per kapita per bulan keluarga contoh, baik pada keluarga ibu bekerja $(51,9 \%)$ maupun pada keluarga ibu tidak bekerja (58,9\%), adalah kurang dari Rp 350.000. Pada keluarga ibu bekerja rata-rata pendapatan per kapita per bulan lebih tinggi (Rp 470.034) daripada keluarga ibu tidak bekerja (Rp 386.182,30). Hal ini disebabkan karena pada keluarga ibu bekerja pendapatan keluarga selain diperoleh dari pendapatan kepala keluarga, juga mendapat sumbangan dari pendapatan ibu. Secara persentase rata-rata jumlah pendapatan yang disumbangkan ibu untuk menambah pendapatan keluarga pada keluarga ibu bekerja adalah $40,9 \%$ dari pendapatan total keluarga. Hasil uji statistik menyatakan tidak terdapat perbedaan yang signifikan antara pendapatan keluarga contoh pada keluarga ibu bekerja dan ibu tidak bekerja.

Hasil penelitian juga menunjukkan bahwa sebagian besar ibu contoh, baik pada keluarga ibu bekerja $(85,2 \%)$ maupun pada keluarga ibu tidak bekerja $(90,4 \%)$, telah memiliki pengetahuan tumbuh kembang yang baik, dan tidak ada satu pun yang memiliki pengetahuan tumbuh kembang yang kurang. Hasil uji statistik menyatakan 
tidak terdapat perbedaan yang signifikan antara pengetahuan ibu contoh mengenai tumbuh kembang pada keluarga ibu bekerja dan keluarga ibu tidak bekerja.

Hasil penelitian menunjukkan bahwa persentase terbesar pekerjaan ibu contoh pada keluarga ibu bekerja $(44,4 \%)$ adalah sebagai pedagang kecil, selebihnya merupakan ibu bekerja dengan jenis pekerjaan meiputi karyawan swasta $(11,1 \%)$, PNS/profesional $(14,8 \%)$, wirausaha $(18,5 \%)$, dan buruh $(11,1 \%)$.

\section{Karakteristik Anak}

Kategori umur contoh dikelompokkan menjadi tiga, yaitu kurang dari 4 tahun ( $<48$ bulan), 4-4,5 tahun (48-54 bulan) dan lebih dari 4,5 tahun (>54 bulan). Hasil penelitian menunjukkan bahwa persentase terbesar contoh pada keluarga ibu bekerja $(48,1 \%)$ berada pada kategori umur lebih dari 4,5 tahun. Sedangkan contoh pada keluarga ibu tidak bekerja $(42,5 \%)$ berada pada kategori umur $<4$ tahun. Rata-rata umur contoh pada keluarga ibu bekerja cenderung lebih tinggi (5,18 bulan) daripada keluarga ibu tidak bekerja ( 49,5 bulan).

Lebih dari separuh contoh berjenis kelamin perempuan, baik pada keluarga ibu bekerja $(51,9 \%)$ maupun pada keluarga ibu tidak bekerja $(52,1 \%)$. Hasil uji statistik menyatakan tidak terdapat perbedaan yang signifikan antara umur dan jenis kelamin contoh pada keluarga ibu bekerja dan keluarga ibu tidak bekerja.

\section{Pemberian ASI}

Pemberian ASI akan berhasil dengan baik bila bayi dibiarkan menyusu sesering mungkin dan ibu mau menyusuinya, serta mempunyai kepercayaan diri bahwa ia mampu mengerjakan hal tersebut (Muchtadi 2002). Pemberian ASI yang dimaksud dalam penelitian ini adalah dilihat dari lamanya ibu memberikan ASI. Berdasarkan Tabel 1 dapat diketahui bahwa lebih dari separuh ibu contoh, baik pada keluarga ibu bekerja maupun pada keluarga ibu tidak bekerja, memberikan ASI kepada contoh selama 1324 bulan. Hasil uji statistik menunjukkan tidak terdapat perbedaan yang signifikan antara lama pemberian ASI pada keluarga ibu bekerja dan keluarga ibu tidak bekerja.

Tidak terdapatnya perbedaan lama pemberian ASI antara keluarga ibu bekerja dan keluarga ibu tidak bekerja diduga karena aktivitas dan keterbatasan waktu ibu tidak menjadi hambatan bagi ibu bekerja untuk tetap memberikan ASI kepada anaknya.

Tabel 1. Sebaran contoh berdasarkan lama pemberian ASI pada keluarga ibu bekerja dan tidak bekerja

\begin{tabular}{lrrrr}
\hline \multirow{2}{*}{$\begin{array}{c}\text { Pemberian } \\
\text { ASI (bulan) }\end{array}$} & \multicolumn{1}{c}{ Ibu Bekerja } & \multicolumn{2}{c}{$\begin{array}{c}\text { Ibu Tidak } \\
\text { Bekerja }\end{array}$} \\
\cline { 2 - 5 } & \multicolumn{1}{c}{$\mathbf{n}$} & \multicolumn{1}{c}{$\%$} & \multicolumn{1}{c}{$\mathbf{n}$} & \multicolumn{1}{c}{$\%$} \\
\hline $0-6$ & 3 & 11,1 & 10 & 13,7 \\
$7-12$ & 1 & 3,7 & 7 & 9,6 \\
$13-24$ & 15 & 55,6 & 43 & 58,9 \\
$>24$ & 8 & 29,6 & 13 & 17,8 \\
\hline \multicolumn{1}{c}{ Total } & 27 & 100,0 & 73 & 100,0 \\
\hline \multicolumn{4}{c}{0 -value } & \multicolumn{5}{c}{0,184} \\
\hline
\end{tabular}

Pontoh (1998) menjelaskan bahwa aktivitas ibu di luar rumah (bekerja) tidak perlu menjadi penghalang untuk terus menyusui. Anak tetap bisa disusui sebelum ibu berangkat bekerja dan setelah pulang dari tempat kerja. Bila selama di tempat kerja payudara ibu terasa penuh, ASI dapat dipompa dan disimpan dalam wadah yang bersih dan kemudian ASI tersebut dapat diberikan kepada bayi di rumah.

\section{Stimulasi Psikososial}

Sementara itu, Tabel 2 menunjukkan bahwa lebih dari separuh orangtua contoh, baik pada keluarga ibu bekerja maupun pada keluarga ibu tidak bekerja, telah memberikan stimulasi psikososial yang cukup baik kepada anaknya di rumah. Rata-rata skor stimulasi psikososial pada kelompok ibu bekerja cenderung lebih tinggi daripada kelompok ibu tidak bekerja yakni masing-masing 39,4 dan 38,9. Namun, hasil uji statistik menunjukkan tidak terdapat perbedaan yang signifikan antara stimulasi psikososial yang diterapkan orangtua contoh pada keluarga ibu bekerja dan keluarga ibu tidak bekerja.

Tabel 2. Sebaran contoh berdasarkan stimulasi psikososial pada keluarga ibu bekerja dan tidak bekerja

\begin{tabular}{crrrr}
\hline \multirow{2}{*}{$\begin{array}{c}\text { Stimulasi } \\
\text { Psikososial }\end{array}$} & \multicolumn{2}{c}{ Ibu Bekerja } & \multicolumn{2}{c}{$\begin{array}{c}\text { Ibu Tidak } \\
\text { Bekerja }\end{array}$} \\
\cline { 2 - 5 } & $\mathbf{n}$ & \multicolumn{1}{c}{$\%$} & $\mathbf{n}$ & \multicolumn{1}{c}{$\%$} \\
\hline Kurang (0-29) & 0 & 0,0 & 2 & 2,7 \\
Sedang (30-45) & 24 & 88,9 & 65 & 89,0 \\
Baik (46-55) & 3 & 11,1 & 6 & 8,2 \\
\hline Total & 27 & 100,0 & 73 & 100,0 \\
\hline Rata-rata $\pm S D$ & $39,4 \pm 4,2$ & \multicolumn{3}{c}{$38,9 \pm 5,1$} \\
\hline p-value & \multicolumn{4}{c}{0,712} \\
\hline
\end{tabular}

Tidak terdapatnya perbedaan stimulasi psikososial antara keluarga ibu bekerja dan 
keluarga ibu tidak bekerja, diduga karena pada keluarga ibu bekerja terdapat pengasuh lain yang menggantikan pengasuhan anak pada saat ibu bekerja. Adanya peranan pengasuh yang dapat mengerti anak, sabar dan telaten membimbing anak, rajin bercakap-cakap dan mampu memberi kesan melindungi menjadi sangat penting agar dapat mengisi kebutuhan anak dalam usaha menjalin kasih sayang dengan lingkungannya (Sidi 1998).

Hasil tersebut menunjukkan bahwa ibu bekerja dapat menyiasati waktu yang terbatas untuk tetap melakukan pengasuhan. Hasil penelitian ini yang menunjukkan bahwa meski ibu bekerja, namun ibu tetap dapat memberikan stimulasi psikososial yang baik, menegaskan beberapa hasil penelitian terdahulu. Hasil penelitian Afwan (1998) menunjukkan bahwa rata-rata alokasi ibu bekerja untuk mengasuh anak (memberikan perhatian seperti menemani bermain, memberi makan serta memberi pengajaran pada anak) pada hari kerja adalah 2,18 jam per hari dan 5,50 jam per hari pada hari libur, sedangkan rata-rata alokasi waktu ibu tidak bekerja adalah 4,80 jam per hari pada hari kerja dan 4,08 jam per hari pada hari libur. Munandar (1985) mengemukakan bahwa bekerjanya ibu tidak menyebabkan dampak negatif yang merugikan bagi perilaku dan penyesuaian diri anak-anaknya. Dalam hal ini yang lebih penting secara psikologis ialah kualitas, bukan kuantitas dari interaksi antara ibu dan anak. Para ahli sependapat bahwa yang paling menentukan bukanlah banyaknya waktu seorang ibu ada bersama anaknya, akan tetapi bagaimana waktu kebersamaan (antara ibu dan anak) itu digunakan.

\section{Perkembangan Sosial-Emosi}

Berdasarkan hasil penelitian diketahui bahwa lebih dari separuh contoh, baik pada keluarga ibu bekerja $(77,8 \%)$ maupun pada keluarga ibu tidak bekerja $(56,2 \%)$, memiliki tingkat perkembangan sosial-emosi yang baik. Rata-rata skor perkembangan sosialemosi contoh pada keluarga ibu bekerja cenderung lebih tinggi $(17,6)$ daripada keluarga ibu tidak bekerja $(16,5)$. Hal ini diduga karena umur anak akan mempengaruhi tingkat perkembangan sosialemosi, dimana rata-rata umur contoh pada keluarga ibu bekerja cenderung lebih tinggi daripada keluarga ibu tidak bekerja. Hasil uji statistik menunjukkan tidak terdapat perbedaan yang signifikan antara perkembangan sosial-emosi contoh pada keluarga ibu bekerja dan keluarga ibu tidak bekerja.

\section{Hubungan Karakteristik Keluarga dengan Lama Pemberian ASI \\ Pendidikan Orangtua. Tabel 3} menunjukkan bahwa persentase terbesar ayah contoh pada semua tingkat pendidikan, berada pada kategori contoh dengan lama pemberian ASI 13-24 bulan dan terdapat kecenderungan bahwa semakin tinggi pendidikan ayah contoh maka lama pemberian ASI semakin menurun. Hasil uji korelasi Spearman menunjukkan terdapat hubungan signifikan negatif antara pendidikan ayah contoh dengan lama pemberian ASI $(p=0,015 ; r=0,243)$. Hal ini dapat terjadi karena dengan semakin tinggi pendidikan seseorang, maka tingkat pendapatannya akan cenderung lebih tinggi sehingga pemberian ASI akan semakin rendah sebagai akibat semakin meningkatnya pembelian susu formula untuk bayi, hal ini sejalan dengan pendapat Berg (1986) yang menyatakan bahwa pembelian susu meningkat pesat proporsinya sehubungan dengan pertambahan pendapatan, tetapi menyusui anak sebaliknya menyusut dengan pesat.

Tabel 3. Sebaran contoh berdasarkan tingkat pendidikan ayah contoh dan lama pemberian ASI

\begin{tabular}{|c|c|c|c|c|c|c|c|c|c|c|}
\hline \multirow{3}{*}{ Pendidikan Ayah } & \multicolumn{10}{|c|}{ Lama Pemberian ASI (bulan) } \\
\hline & \multicolumn{2}{|c|}{$0-6$} & \multicolumn{2}{|c|}{$7-12$} & \multicolumn{2}{|c|}{$13-24$} & \multicolumn{2}{|c|}{$>24$} & \multicolumn{2}{|c|}{ Total } \\
\hline & $\mathbf{n}$ & $\%$ & $\mathbf{n}$ & $\%$ & $\mathbf{n}$ & $\%$ & $\mathbf{n}$ & $\%$ & $\mathbf{n}$ & $\%$ \\
\hline Tidak sekolah & 0 & 0,0 & 0 & 0,0 & 0 & 0,0 & 0 & 0,0 & 0 & 0,0 \\
\hline SD & 0 & 0,0 & 0 & 0,0 & 12 & 70,6 & 5 & 29,4 & 17 & 100,0 \\
\hline SMP & 2 & 12,5 & 1 & 6,3 & 9 & 56,0 & 4 & 25,0 & 16 & 100,0 \\
\hline SMA & 7 & 13,5 & 5 & 9,6 & 30 & 57,7 & 10 & 19,2 & 52 & 100,0 \\
\hline PT & 4 & 26,7 & 2 & 13,3 & 7 & 46,7 & 2 & 13,3 & 15 & 100,0 \\
\hline Total & 13 & 13,0 & 8 & 8,0 & 58 & 58,0 & 21 & 21,0 & 100 & 100,0 \\
\hline
\end{tabular}

Sementara itu, dari Tabel 4 dapat dilihat bahwa secara umum pada semua tingkat

pendidikan ibu, contoh telah diberikan ASI
selama 13-24 bulan, namun terdapat ibu 
yang memberikan ASI lebih dari 24 bulan yaitu pada ibu yang tidak sekolah. Jika dilihat dari jenis pekerjaan, ibu tersebut memiliki pekerjaan sebagai buruh cuci, diduga bahwa pekerjaan ibu tersebut tidak menghabiskan banyak waktu ibu untuk bersama dengan anaknya sehingga pemberian ASI lebih dari 24 bulan dapat dilakukan oleh ibu. Selain itu, berdasarkan hasil penelitian menunjukkan bahwa ibu tersebut memiliki pengetahuan tumbuh kembang yang baik sehingga dengan pengetahuan tersebut ibu memberikan ASI lebih dari 24 bulan. Hasil uji korelasi Spearman menyatakan tidak terdapat hubungan yang signifikan antara pendidikan ibu contoh dengan lama pemberian ASI.

\section{Pendapatan per Kapita}

Pada Tabel 5 dapat terlihat bahwa pada semua tingkat pendapatan per kapita keluarga, persentase terbesar adalah keluarga yang mempunyai contoh yang memperoleh ASI selama 13-24 bulan. Hasil uji korelasi Spearman menunjukkan bahwa terdapat hubungan yang signifikan negatif antara pendapatan per kapita keluarga contoh dengan lama pemberian ASI $\left(p=0,004 ; r=-0,283^{* *}\right)$. Hal ini berarti terdapat kecenderungan bahwa semakin meningkat pendapatan per kapita suatu keluarga, maka semakin menurun lama pemberian ASI. Temuan ini menegaskan bahwa lama pemberian ASI juga berhubungan negatif dengan tingkat pendidikan ayah yang juga menjadi temuan penelitian ini. Hal tersebut sejalan dengan pendapat Berg (1986) yang menyatakan bahwa sehubungan dengan pertambahan pendapatan, menyusui anak menyusut dengan pesat tetapi pembelian susu meningkat pesat proporsinya.

\section{Pengetahuan Tumbuh Kembang}

Tabel 6 menunjukkan bahwa tidak ada satu pun ibu contoh yang memiliki pengetahuan tumbuh kembang yang kurang. Ibu contoh yang memiliki pengetahuan tumbuh kembang yang cukup dan baik persentase terbesar telah memberikan ASI selama 13-24 bulan. Hasil uji korelasi Spearman menyatakan tidak terdapat hubungan yang signifikan antara pengetahuan ibu contoh mengenai tumbuh kembang dengan lama pemberian ASI.

\section{Hubungan Karakteristik Anak dengan Lama Pemberian ASI \\ Jenis Kelamin. Berdasarkan jenis} kelamin contoh, hasil penelitian ini menunjukkan bahwa contoh, baik yang berjenis kelamin laki-laki maupun perempuan, persentase terbesar diberikan ASI selama 13-24 bulan. Selain itu, dapat dilihat pula bahwa persentase contoh yang berjenis kelamin perempuan yang diberikan ASI lebih dari 24 bulan lebih besar daripada contoh yang berjenis kelamin laki-laki (Tabel 7). Namun hasil uji korelasi Spearman menyatakan tidak terdapat hubungan yang signifikan antara jenis kelamin contoh dengan lama pemberian ASI.

Tabel 4. Sebaran contoh berdasarkan tingkat pendidikan ibu contoh dan lama pemberian ASI

\begin{tabular}{|c|c|c|c|c|c|c|c|c|c|c|}
\hline \multirow{3}{*}{ Pendidikan Ayah } & \multicolumn{10}{|c|}{ Lama Pemberian ASI (bulan) } \\
\hline & \multicolumn{2}{|c|}{$0-6$} & \multicolumn{2}{|c|}{$7-12$} & \multicolumn{2}{|c|}{$13-24$} & \multicolumn{2}{|c|}{$>24$} & \multicolumn{2}{|c|}{ Total } \\
\hline & $\mathbf{n}$ & $\%$ & $\mathbf{n}$ & $\%$ & $\mathbf{n}$ & $\%$ & $\mathbf{n}$ & $\%$ & $\mathbf{n}$ & $\%$ \\
\hline Tidak sekolah & 0 & 0,0 & 0 & 0,0 & 0 & 0,0 & 1 & 100,0 & 1 & 100,0 \\
\hline SD & 0 & 0,0 & 1 & 4,3 & 18 & 78,3 & 4 & 17,4 & 23 & 100,0 \\
\hline SMP & 4 & 12,9 & 1 & 3,2 & 20 & 64,5 & 6 & 19,4 & 31 & 100,0 \\
\hline SMA & 9 & 23,1 & 5 & 12,8 & 17 & 43,6 & 8 & 20,5 & 39 & 100,0 \\
\hline PT & 0 & 0,0 & 1 & 16,7 & 3 & 50,0 & 2 & 33,3 & 6 & 100,0 \\
\hline Total & 13 & 13,0 & 8 & 8,0 & 58 & 58,0 & 21 & 21,0 & 100 & 100,0 \\
\hline
\end{tabular}

Tabel 5. Sebaran contoh berdasarkan pendapatan per kapita dan lama pemberian ASI

\begin{tabular}{|c|c|c|c|c|c|c|c|c|c|c|}
\hline \multirow{3}{*}{ Pendapatan (Rp) } & \multicolumn{10}{|c|}{ Lama Pemberian ASI (bulan) } \\
\hline & \multicolumn{2}{|c|}{$0-6$} & \multicolumn{2}{|c|}{$7-12$} & \multicolumn{2}{|c|}{ 13-24 } & \multicolumn{2}{|c|}{$>24$} & \multicolumn{2}{|c|}{ Total } \\
\hline & $\mathbf{n}$ & $\%$ & $\mathbf{n}$ & $\%$ & $\mathbf{n}$ & $\%$ & $\mathbf{n}$ & $\%$ & $\mathbf{n}$ & $\%$ \\
\hline$<350.000,00$ & 4 & 7,0 & 2 & 3,5 & 39 & 68,4 & 12 & 21,1 & 57 & 100,0 \\
\hline $350.000,00-450.000,00$ & 2 & 11,8 & 2 & 11,8 & 8 & 47,1 & 5 & 29,4 & 17 & 100,0 \\
\hline$>450.000,00$ & 7 & 26,9 & 4 & 15,4 & 11 & 42,3 & 4 & 15,4 & 26 & 100,0 \\
\hline Total & 13 & 13,0 & 8 & 8,0 & 58 & 58,0 & 21 & 21,0 & 100 & $\overline{100,0}$ \\
\hline
\end{tabular}

Tabel 6. Sebaran contoh berdasarkan pengetahuan ibu mengenai tumbuh kembang dan lama pemberian ASI 


\begin{tabular}{|c|c|c|c|c|c|c|c|c|c|c|}
\hline \multirow{3}{*}{ Pengetahuan Tumbuh Kembang } & \multicolumn{10}{|c|}{ Lama Pemberian ASI } \\
\hline & \multicolumn{2}{|c|}{$0-6$} & \multicolumn{2}{|c|}{$7-12$} & \multicolumn{2}{|c|}{$13-24$} & \multicolumn{2}{|c|}{$>24$} & \multicolumn{2}{|c|}{ Total } \\
\hline & $\mathbf{n}$ & $\%$ & $\mathbf{n}$ & $\%$ & $\mathbf{n}$ & $\%$ & $\mathbf{n}$ & $\%$ & $\mathbf{n}$ & $\%$ \\
\hline Kurang & 0 & 0,0 & 0 & 0,0 & 0 & 0,0 & 0 & 0,0 & 0 & $\overline{0,0}$ \\
\hline Sedang & 1 & 9,1 & 2 & 18,2 & 5 & 45,5 & 3 & 27,3 & 11 & 100,0 \\
\hline Baik & 12 & 13,5 & 6 & 6,7 & 53 & 59,6 & 18 & 20,2 & 89 & 100,0 \\
\hline Total & 13 & 13,0 & 8 & 8,0 & 58 & 58,0 & 21 & 21,0 & 100 & 100,0 \\
\hline
\end{tabular}

Tabel 7. Sebaran contoh berdasarkan jenis kelamin contoh dan lama pemberian ASI

\begin{tabular}{|c|c|c|c|c|c|c|c|c|c|c|}
\hline \multirow{3}{*}{ Jenis Kelamin } & \multicolumn{10}{|c|}{ Lama Pemberian ASI } \\
\hline & \multicolumn{2}{|c|}{$0-6$} & \multicolumn{2}{|c|}{$7-12$} & \multicolumn{2}{|c|}{$13-24$} & \multicolumn{2}{|c|}{$>24$} & \multicolumn{2}{|c|}{ Total } \\
\hline & $\mathbf{n}$ & $\%$ & $\mathbf{n}$ & $\%$ & $\mathbf{n}$ & $\%$ & $\mathbf{n}$ & $\%$ & $\mathbf{n}$ & $\%$ \\
\hline Laki-laki & 8 & 16,7 & 4 & 8,3 & 29 & 60,4 & 7 & 14,6 & 48 & 100,0 \\
\hline Perempuan & 5 & 9,6 & 4 & 7,7 & 29 & 55,8 & 14 & 26,9 & 52 & 100,0 \\
\hline Total & 13 & 13,0 & 8 & 8,0 & 58 & 58,0 & 21 & 21,0 & 100 & 100,0 \\
\hline
\end{tabular}

\section{Hubungan Karakteristik Keluarga dengan Stimulasi Psikososial \\ Pendidikan Orangtua. Sementara itu,} hubungan antara pendidikan ayah dengan pemberian stimulasi psikososial menunjukkan bahwa stimulasi psikososial paling baik adalah pada ayah contoh yang memiliki tingkat pendidikan Perguruan Tinggi dan terdapat kecenderungan bahwa semakin tinggi pendidikan ayah contoh, maka semakin tinggi pula skor stimulasi psikososial (Gambar 1). Hasil uji korelasi Spearman menunjukkan bahwa terdapat hubungan yang signifikan positif antara pendidikan ayah contoh dengan stimulasi psikososial $\left(p=0,000 ; r=0,453^{* *}\right)$.

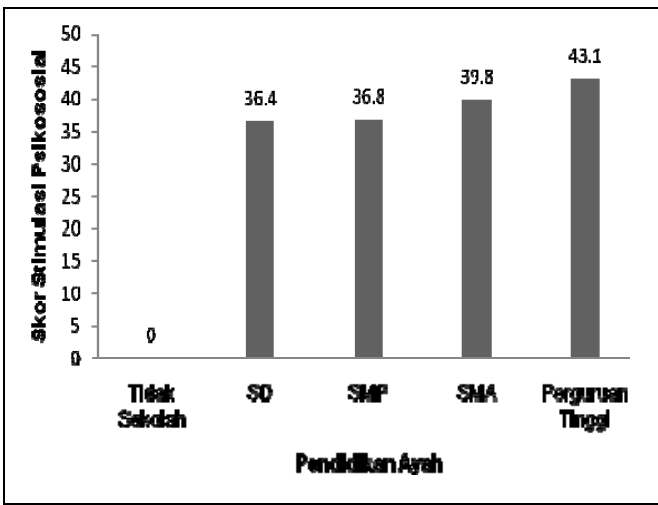

Gambar 1. Sebaran contoh berdasarkan tingkat pendidikan ayah dan skor stimulasi psikososial

Berdasarkan pendidikan ibu stimulasi psikososial paling baik adalah juga pada ibu contoh yang memiliki tingkat pendidikan Perguruan Tinggi dan terlihat kecenderungan bahwa semakin tinggi pendidikan ibu contoh, maka semakin tinggi pula skor stimulasi psikososial (Gambar 2). Sama halnya dengan pendidikan ayah, hasil uji korelasi Spearman menunjukkan bahwa terdapat hubungan yang signifikan positif antara pendidikan ibu contoh dengan stimulasi psikososial $\left(p=0,000 ; r=0,411^{* *}\right)$. Kedua temuan tersebut menegaskan bahwa semakin baik tingkat pendidikan orangtua berhubungan erat dengan semakin baiknya kualitas stimulasi psikososial yang diberikan kepada anaknya.

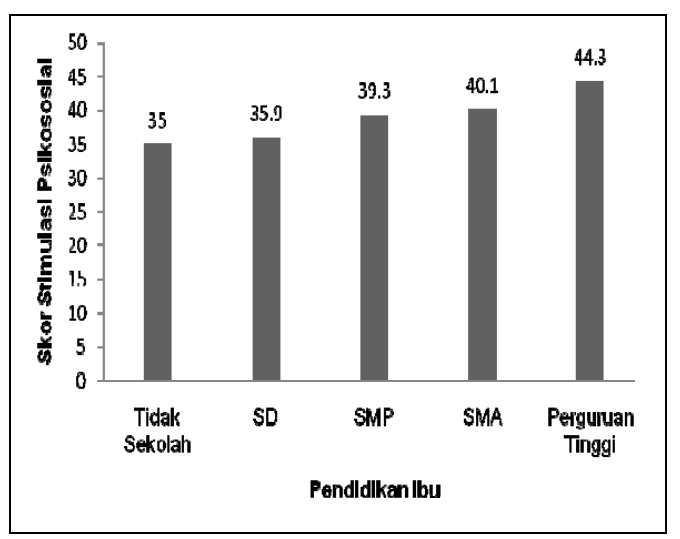

Gambar 2. Sebaran contoh berdasarkan tingkat pendidikan ibu dan skor stimulasi psikososial

Pendapatan per Kapita. Pada Gambar 3 dapat dilihat bahwa stimulasi psikososial paling baik adalah pada keluarga yang memiliki pendapatan per kapita lebih dari Rp 450.000. Gambar 3 menunjukkan kecenderungan bahwa semakin meningkat 
pendapatan per kapita suatu keluarga, maka semakin meningkat pula skor stimulasi psikososial. Hasil uji korelasi Spearman menunjukkan bahwa terdapat hubungan yang signifikan positif antara pendapatan per kapita keluarga contoh dengan stimulasi psikososial $\left(p=0,000 ; r=0,506^{\star *}\right)$.

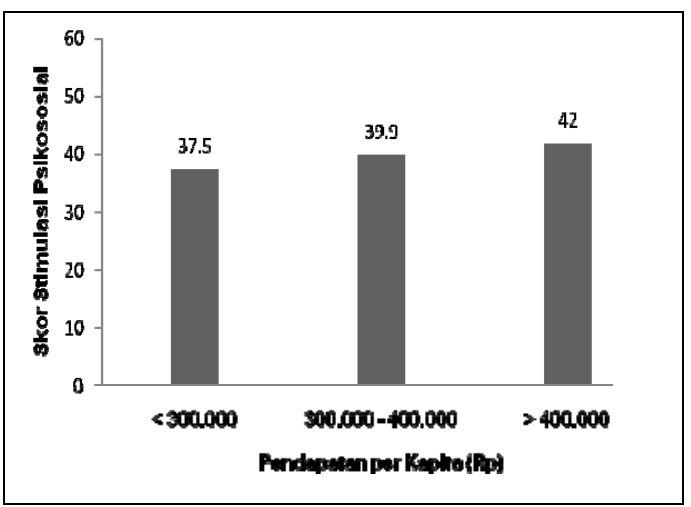

Gambar 3. Sebaran contoh berdasarkan tingkat pendapatan per kapita dan skor stimulasi psikososial

Pengetahuan Tumbuh Kembang. Pada Gambar 4 terlihat kecenderungan bahwa semakin baik pengetahuan ibu mengenai tumbuh kembang, maka semakin baik pula stimulasi psikososial. Hasil uji korelasi Spearman menunjukkan bahwa terdapat hubungan yang signifikan positif antara pengetahuan ibu contoh mengenai tumbuh kembang dengan stimulasi psikososial $\left(p=0,010 ; r=0,257^{\star *}\right)$.

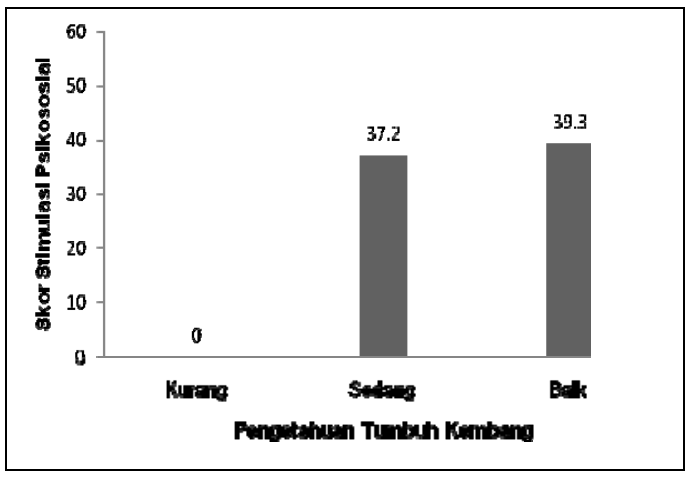

Gambar 4. Sebaran contoh berdasarkan tingkat pengetahuan ibu mengenai tumbuh kembang dan skor stimulasi psikososial

\section{Hubungan Karakteristik Anak dengan Stimulasi Psikososial}

Umur Anak. Gambar 5 menunjukkan bahwa stimulasi psikososial paling baik pada contoh yang berusia lebih dari 4,5 tahun, namun hasil korelasi Spearman menyatakan bahwa tidak terdapat hubungan yang signifikan antara umur contoh dengan stimulasi psikososial.

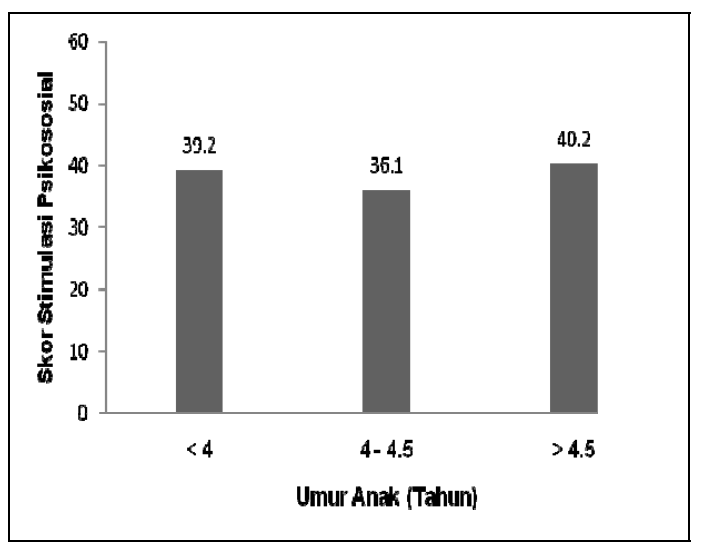

Gambar 5. Sebaran contoh berdasarkan umur contoh dan skor stimulasi psikososial

Jenis Kelamin. Sementara itu, Gambar 6 menunjukkan bahwa contoh yang berjenis kelamin perempuan menerima stimulasi psikososial lebih baik dibandingkan contoh yang berjenis kelamin laki-laki. Temuan ini kemungkinan terjadi karena contoh yang berjenis kelamin perempuan memiliki respon lebih positif terhadap stimulasi yang diberikan. Adanya respon positif tersebut, menyebabkan orangtua akan memberikan stimulasi yang semakin positif pula. Hal ini sejalan dengan teori operant-conditioning yang dipopulerkan oleh Skinner, dimana teori tersebut menjelaskan bahwa adanya respon atau jawaban, maka akan menimbulkan penguatan atau rangsangan (Gunarsa 2003). Hasil uji korelasi Spearman menyatakan bahwa terdapat hubungan yang signifikan negatif antara jenis kelamin contoh dengan stimulasi psikososial. 


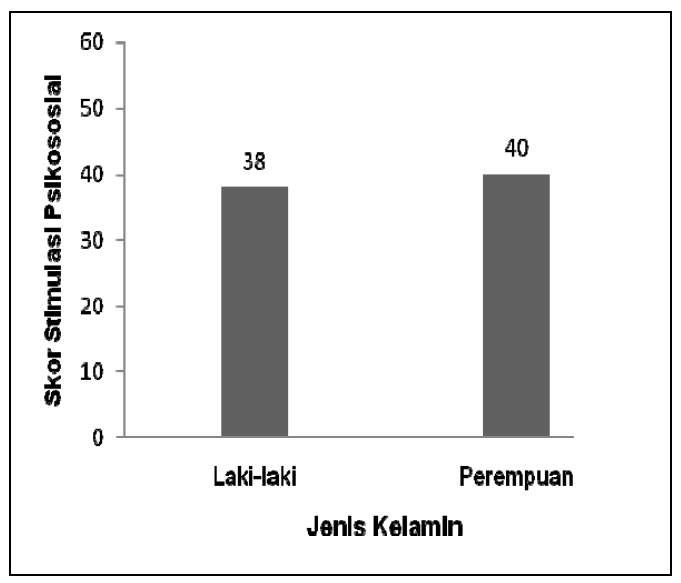

Gambar 6. Sebaran contoh berdasarkan jenis kelamin contoh dan skor stimulasi psikososial

\section{Faktor-faktor yang Mempengaruhi Per- kembangan Sosial-Emosi Anak}

Dari hasil uji regresi linier berganda antara karakteristik keluarga (pendapatan keluarga, pendidikan ibu, pengetahuan ibu mengenai tumbuh kembang, dan status pekerjaan ibu), karakteristik anak (umur dan jenis kelamin), lama pemberian ASI, dan stimulasi psikososial terhadap perkembangan sosial-emosi anak diperoleh hasil bahwa stimulasi psikososial dan umur anak merupakan faktor yang dominan dalam mempengaruhi perkembangan sosial-emosi anak.

Stimulasi psikososial menjadi salah satu faktor yang dominan mempengaruhi perkembangan sosial-emosi anak. Hal ini sejalan dengan hasil penelitian Yuliana (2007) yang menunjukkan bahwa stimulasi psikososial berpengaruh secara signifikan terhadap perkembangan sosial-emosi anak. Soetjiningsih (1995) menambahkan bahwa stimulasi merupakan hal yang penting dalam tumbuh kembang anak. Anak yang mendapat stimulasi yang terarah dan teratur akan lebih cepat berkembang dibandingkan dengan anak yang kurang atau tidak mendapat stimulasi. Berdasarkan hasil regresi diperoleh hasil bahwa setiap peningkatan satu satuan skor stimulasi psikososial akan meningkatkan 0,427 satuan skor perkembangan sosial-emosi anak.

Selain itu, perkembangan sosial-emosi anak juga dipengaruhi oleh umur anak. Erikson dalam Hastuti (2006) menyatakan bahwa perkembangan berjalan dalam tahapan menurut umur. Berdasarkan hasil regresi diperoleh hasil bahwa setiap penambahan satu satuan skor umur anak akan meningkatkan 0,218 satuan skor perkembangan sosial-emosi anak.

Nilai Adjusted $R^{2}$ hasil uji regresi linier berganda model dalam penelitian ini adalah $1,17 \%$ faktor yang berpengaruh terhadap perkembangan sosial-emosi anak dapat dijelaskan dari hasil regresi, sedangkan sisanya $(82,3 \%)$ dijelaskan oleh variabel lain yang tidak diteliti dalam penelitian ini. Hasil uji regresi linier dari faktor-faktor yang berpengaruh terhadap perkembangan sosialemosi dapat dilihat pada Tabel 8.

Tabel 8. Hasil uji regresi dari faktor-faktor yang berpengaruh terhadap perkembangan sosialemosi anak

\begin{tabular}{|c|c|c|c|c|c|}
\hline & \multicolumn{2}{|c|}{ Tidak Terstandardisasi } & \multirow{2}{*}{$\frac{\text { Terstandardisasi }}{\beta}$} & \multirow{2}{*}{$\mathbf{t}$} & \multirow{2}{*}{ Sig } \\
\hline & B & Std. error & & & \\
\hline $\mathrm{C}$ & $-1,522$ & 4,725 & & $-0,322$ & 0,748 \\
\hline $\mathrm{X} 1$ & 1,17E-006 & 0,000 & 0,119 & 1,074 & 0,286 \\
\hline $\mathrm{X} 2$ & $-0,189$ & 0,120 & $-0,164$ & $-1,567$ & 0,121 \\
\hline$\times 3$ & $-0,052$ & 0,288 & $-0,018$ & $-0,182$ & 0,856 \\
\hline$\times 4$ & 0,822 & 0,652 & 0,120 & 1,260 & 0,211 \\
\hline$\times 5$ & 0,140 & 0,061 & 0,218 & 2,287 & $0,024^{*}$ \\
\hline$\times 6$ & 0,297 & 0,392 & 0,077 & 0,756 & 0,451 \\
\hline$\times 7$ & 0,301 & 0,079 & 0,427 & 9,817 & $0,000^{* *}$ \\
\hline D8 & 0,370 & 0,728 & 0,048 & 0,507 & 0,613 \\
\hline $\mathrm{R}^{2}$ & & & 0,244 & & \\
\hline $\operatorname{Adj} R^{2}$ & & & 0,177 & & \\
\hline
\end{tabular}

Ket: C (constant); X1 (pendapatan keluarga); X2 (pendidikan ibu); X3 (pengetahuan ibu); X4 (jenis kelamin anak); X5 (umur anak); X6 (pemberian ASI); X7 (stimulasi psikososial); D8 (dummy kerja ibu);

* (signifikan pada taraf $p<0,05)$;

** (signifikan pada taraf $p<0,01)$. 
Dalam penelitian ini, lama pemberian ASI tidak mempengaruhi perkembangan sosial-emosi anak. Diduga terdapat faktor lain yang mempengaruhi perkembangan sosial-emosi anak diantaranya adalah emotional bonding, kelompok bermain dan teman sebaya (peer group) yang tidak diteliti dalam penelitian ini.

Berdasarkan hasil penelitian Hastuti (2006) menunjukkan bahwa emotional bonding memiliki hubungan yang signifikan positif dengan stimulasi psikososial. Hal ini berarti bahwa semakin erat emotional bonding antara ibu dan anak maka stimulasi yang diberikan pun akan semakin baik, selanjutnya stimulasi akan mempengaruhi kualitas anak.

Kelompok bermain adalah bentuk layanan bagi anak usia dini (3-6 tahun) yang berfungsi untuk membantu meletakkan dasar-dasar ke arah perkembangan sikap, pengetahuan, dan keterampilan yang diperlukan bagi anak usia dini dalam menyesuaikan diri dengan lingkungannya dan untuk pertumbuhan serta perkembangan selanjutnya. Kelompok bermain yang baik harus dapat menyediakan sarana dan program pembelajaran yang memadai bagi proses pendidikan dan perkembangan anak, yang tentunya disesuaikan dengan tahapan perkembangan dan usia anak (Depdiknas 2002). Hasil penelitian Sulistyani (2006) menunjukkan bahwa program dan sarana pembelajaran di kelompok bermain merupakan salah satu faktor dominan yang mempengaruhi perkembangan sosial-emosi anak. Hal ini berarti bahwa dengan program dan sarana pembelajaran yang baik di kelompok bermain maka perkembangan sosial-emosi anak akan semakin baik pula.

Faktor lain yang diduga mempengaruhi perkembangan sosial-emosi anak adalah teman sebaya (peer group). Santrock (1995) dalam Desmita (2005) menjelaskan bahwa berdasarkan hasil penelitian yang dilakukan oleh para ahli perkembangan menunjukkan bahwa hubungan yang baik antar teman sebaya memilik peran penting dalam perkembangan yang normal, dalam hal ini adalah perkembangan sosial-emosi anak.

\section{KESIMPULAN DAN SARAN}

\section{Kesimpulan}

Hasil penelitian menunjukkan lebih dari separuh contoh, baik pada keluarga ibu bekerja maupun pada keluarga ibu tidak bekerja, memberikan ASI dengan lama pemberian ASI 13-24 bulan dan telah memberikan stimulasi psikososial yang cukup baik kepada anaknya di rumah. Berdasarkan hasil analisis, variabel pendidikan ayah dan pendapatan keluarga berhubungan signifikan (negatif) dengan variabel lama pemberian ASI. Sementara itu, pendidikan ayah, pendidikan ibu, pendapatan keluarga, dan pengetahuan ibu mengenai tumbuh kembang berhubungan secara signifikan (positif) dengan stimulasi psikososial. Jenis kelamin berhubungan secara signifikan (negatif) dengan stimulasi psikososial, yaitu anak yang berjenis kelamin perempuan memperoleh stimulasi psikososial yang lebih baik daripada anak yang berjenis kelamin laki-laki. Stimulasi psikososial dan umur anak merupakan faktor yang dominan dalam mempengaruhi perkembangan sosial-emosi anak, sedangkan pemberian ASI tidak mempengaruhi perkembangan sosial-emosi anak.

\section{Saran}

Secara umum baik pada keluarga ibu bekerja maupun keluarga ibu tidak bekerja telah memberikan stimulasi psikososial yang cukup baik, namun dalam hal stimulasi belajar (seperti: ketersediaan mainan yang memiliki peraturan, buku, majalah, dan koran) dan stimulasi bahasa (seperti: katakata ibu selalu menyenangkan) masih kurang. Oleh karena itu, masih perlu ditingkatkan pemberian stimulasi psikososial, khususnya dalam hal-hal ketersediaan mainan yang memiliki peraturan, buku, majalah, koran serta kata-kata ibu yang seharusnya selalu menyenangkan, sehingga perkembangan sosial-emosi anak dapat lebih baik. Hal ini mengingat bahwa stimulasi psikososial merupakan salah satu faktor dominan yang mempengaruhi perkembangan sosial-emosi anak.

Mengingat keterbatasan penelitian, maka untuk penelitian selanjutnya disarankan untuk meneliti riwayat pemberian ASI khususnya dalam hal sikap dan perilaku ibu pada saat memberikan ASI, dukungan sosial keluarga terhadap pemberian ASI, alokasi waktu ibu khususnya dalam hal memberikan stimulasi psikososial, dan pengaruh teman sebaya terhadap perkembangan sosial-emosi. 


\section{UCAPAN TERIMA KASIH}

Terima kasih disampaikan kepada ibu Ir. Lilik Noor, MFSA atas bimbingan dan partisipasinya dalam kegiatan penelitian.

\section{DAFTAR PUSTAKA}

Afwan RM. 1998. Perkembangan Anak Usia 3-5 Tahun pada Keluarga Ibu Bekerja dan Ibu Tidak Bekerja, serta FaktorFaktor yang Mempengaruhinya [skripsi]. Bogor: Fakultas Pertanian, Institut Pertanian Bogor.

Berg A. 1986. Peranan Gizi dalam Pembangunan Nasional. Jakarta: Rajawali.

Darmadji S, Patmonodewo S, Atmodiwirjo ET, Hadis FA, Lestari H. 1984. Perkembangan Anak Balita, Program Bina Keluarga dan Balita, Buku IV. Jakarta: Kantor Menteri Negara Urusan Peranan Wanita.

Desmita. 2005. Psikologi Perkembangan. Bandung: Remaja Rosdakarya.

[Depdiknas] Departemen Pendidikan Nasional. 2002. Acuan Menu Pembelajaran pada Pendidikan Anak Usia Dini (Menu Pembelajaran Generik). Jakarta: Depdiknas. 2004. Instrumen Penelitian Kompetensi (Perkembangan) Anak Usia 3,5-6,4 Tahun. Jakarta: Pusat Kurikulum, Badan Penelitian dan Pengembangan, Departemen Pendidikan Nasional.

Gunarsa SD. 2003. Dasar dan Teori Perkembangan Anak. Jakarta: BPK Gunung Mulia.

\footnotetext{
* Korespondensi :

Telp : +62-251 8628303

Email : mellylatifah@yahoo.com
}

Hastuti D. 2006. Analisis Pengaruh Model Pendidikan Prasekolah pada Pembentukan Anak Sehat, Cerdas dan Berkarakter [disertasi]. Bogor: Fakultas Pertanian, Institut Pertanian Bogor.

Megawangi R. 2004. Pendidikan Karakter (Solusi yang Tepat untuk Membangun Bangsa). Jakarta: Indonesia Heritage Foundation.

Muchtadi D. 2002. Gizi untuk Bayi: ASI, Susu Formula, dan Makanan Tambahan. Jakarta: Pustaka Sinar Harapan.

Munandar U. 1985. Emansipasi dan Peran Ganda Wanita Indonesia (Suatu Tinjauan Psikologis). Jakarta: UI Press.

Pontoh RS. 1998. Mengungkapkan Cinta Melalui ASI. Ayah Bunda: 45.

Roesli U. 2000. Seri 1 (Mengenal ASI Eksklusif). Jakarta: Trubus Agriwidya.

Sidi S. 1998. Sentuhan Cinta Ibu Masa Kini. Ayah Bunda:132.

Soetjiningsih. 1995. Tumbuh Kembang Anak. Di dalam: IGN Gde Ranuh, editor. Jakarta: EGC.

Sulistyani W. 2006. Pengaruh Stimulasi Psikososial di Kelompok Bermain dan Pengasuhan di Rumah terhadap Perkembangan Sosial-Emosi Anak Usia 2-4 Tahun di Kota Bogor [skripsi]. Bogor: Fakultas Pertanian, Institut Pertanian Bogor.

Umar H. 2000. Riset Pemasaran dan Perilaku Konsumen. Jakarta: Gramedia.

Yuliana. 2007. Pengaruh Penyuluhan Gizi dan Stimulasi Psikososial terhadap Pertumbuhan dan Perkembangan Anak Usia Prasekolah [disertasi]. Bogor: Fakultas Pertanian, Institut Pertanian Bogor. 